\title{
Meie esivanemate rahvatarkus ja maailmapilt: mida keel mäletab?
}

\author{
$\underline{\text { Urmas Sutrop }}$
}

Ajakirja "Vikerkaar" evolutsiooniteooriatele pühendatud erinumbris küsisin artiklis evolutsioonilisest psühholoogiast, kas meie teadvus on pärit kiviajast. Selle loo järeldusi oli, et suur osa meie teadvusest ning ainult kaduvväike osa tänapäeva kultuurist pärineb kiviajast. Näitasin, et tänapäevaste uurimismeetoditega on võimalik rekonstrueerida meie küttidest-korilastest esivanemate käitumist ja teisalt rekonstrueerida keskkonda, kus nad elasid (Sutrop 1999). Käesolevas loos vaatame, mida keel mäletab ja kuidas selle abil on võimalik rekonstrueerida meie esivanemate rahvatarkust ja maailmapilti.

Maailmapildi all ei mõista ma mingit filosoofilist terminit, ega ka paleoastronoomiast pärit definitsiooni, mille järgi maailmapilt on see, mis meile parajasti taevast paistab, s.t tähtede asendit meie ajastul. Maailmapilt on siin argimõiste, mis väljendab meie või meie esivanemate arusaama maailmast, asjade ja nähtuste vahelistest seostest jne. Maailmapilt juhib kõige üldisemalt inimeste elu ja käitumist.

Maailmapildis on lihtsamaid ja keerukamaid osi. Maailmapilti võib jagada inimese tegevusvaldkondade järgi osadeks. Maailmapilti kuuluvad suheted teiste inimeste ja loodusega, siin- ja teispoolsus, maailma ruumilisus ja terviklikkus. Me saame maailmapilti jagada ka asiseks ja mentaalseks. Mentaalne maailmapilt ongi kõige huvitavam, aga ka kõige raskemini tabatav. Mentaalsesse maailmapilti kuuluvad niisugused mõisted nagu ise, hing, vaim, meel, jumal jt.

Rahva maailmapildi aluseks on rahvatarkus. Rahvatarkus struktureerib maailma ja sellele vastava maailmapildi. Rahvatarkust kasutan eestikeelse vastena ingliskeelsetele terminitele folk model, folk theory või ka naive model, naive theory. Rahvatarkuse põlvest põlve edasiandmisel on kõige olulisem keel. Muutuvad aga mõlemad, nii maailmapilt kui keel. Järgnevas püüan näidata, et keel mäletab vana rahvatarkust ja sellele vastavat maailmapilti, ilma et keele kandjad, s.t meie ise seda märkaksimegi.

Keele mälu uurib keelepsühholoogia. Rahvapsühholoogia (vahel ka etnopsühholoogiaks kutsutud) uurib rahvuslikku iseloomu (vt Tulviste 1998). Muistset rahvatarkust ning sellele vastavat maailmapilti saame uurida, kui me arvestame nii keelepsühholoogiat (keelemälu) kui rahvapsühholoogiat. Selliseid uurimusi on meil veel vähe. Kuna ei ole harjutud sel teemal diskuteerima, siis vahel ei pane uurijad varemtehtut tähelegi.

Käesoleva kirjutise esimeses osas vaatlen sissejuhatavalt mõningaid lihtsamaid maailmapildi avaldumise juhte eesti keeles ning töö teises osas analüüsin meie esivanemate mentaalse maailmapildi olulisi mõisteid nagu hing, vaim ja meel. Samuti osutan vajadusele edaspidi keelematerjali analüüsil eristada võõrmõjud ning seejärel tuua välja meie esivanemate (mentaalse) maailmapildi erinevad kihistused. Vastasel korral võime sünkroonse keelematerjali analüüsi põhjal teha valesid järeldusi. 


\section{Mida keel mäletab?}

Uku Masing kurdab oma programmilises artiklis "Hüpoteetilist eesti keele psühholoogiast" 1933. aastal, et enam-vähem korralikku keelepsühholoogiat on olemas ainult klassikaliste surnud keelte kohta, eesti keele alal pole midagi ära tehtud (Masing [1933] 1993: 52). Praeguseks seda enam ütelda ei saa. Peale Uku Masingu on keelemälu abil meie esivanemate maailmapilti rekonstrueerinud veel Paul Alvre ([1962] 1989) ja Haldur Õim (1997). Rahvatarkust ja rahva kadunud maailmapilti saab kokku korjata ka ainelise rahvakultuuri säilinud esemetest või vaimse rahvaloomingu mitmetest vormidest, nagu rahvalaulud, muinasjutud, muistendid ja vanasõnad. Keelemälu erineb rahva vaimsest loomingust selle poolest, et see esineb keelevormide ja keelekasutusena igasuguses situatsioonis. Me leiame keelemälu igapäevasest kõnest, ajalehetekstidest, ilukirjandusest, vanadest raamatutest, ka rahvalauludest jm. Keelemälu peidab end nii sõnavaras, fraseoloogias, süntaksis kui ka morfoloogias.

Vaatleme kõigepealt mõnda näidet keelemälust. Igapäevases kõnes palume tihti, et keegi paneks tule põlema või kustutaks tule ära. Ometi vajutatakse seepeale ainult lambilülitit. Samuti teevad paljud meist tule pliidi alla või panevad teekannu tulele ka siis, kui kasutatakse elektripliiti. Juba nendest lihtsatest igapäevastest näidetest on näha, kuidas keel mäletab puupliite, millele tehti tuli alla, või varasemaid valguseallikaid, mis tõepoolest pandi põlema ja pärast kustutati ära (peerud või ka petrooleumilamp). Kui me teeme akna lahti, ka siis ei võta me seda enam ammu lahti, s.t eest ära, vaid avame. Ka niisugused näited iseloomustavad maailmapilti, vähemalt selle lihtsamaid osi. Paljud meie uuslinnaosade elanikud on mugavuste keskele sattunud varasemast puupliitidega maailmast. Paljud aga pole veel sellest maailmast välja saanudki.

Võtame nüüd mõne keerukama näite, mis pole asise kultuuriga seotud. Päike läheb igal õhtul looja. Aga kuhu ta siis läheb, hoopis Maa pöörleb ju? Siin mäletab meie keel ikka veel meie varasemat maailmapilti, kus Päike oli tegus isikustatud tegelane, kes tõepoolest läks looja. Hommikul ta idanes, s.t tõusis idast, et oma uut päevast ringkäiku alustada. Kui meist aga keegi sureb, siis ta lahkub meie hulgast. Muistne rahvatarkus teadis, et surnu läheb kuhugi mujale, läheb meie hulgast ära. Meie keel mäletab seda kunagist uskumust, mida me ise enam ei jaga.

Meie ajaarvamine on olnud ajast aega (sellest ka lühenenult aasta) valgete päevade järgi. Seda tunnistavad meie kõikvõimalikud tähtpäevad. Meie naabrid indogermaanid aga arvasid aega pimeduses ööst öösse; näiteks meil vastlapäev ja sakslastel Fastnacht (vastlaöö) või Fastelabend (vastlaõhtu). Kui me ka vahel pühitseme mõnd õhtut või ööd, siis oleme sellise kombe õppinud sakslastelt.

Uku Masing kirjutab, et "iga eestlane arvab, et ta teab, mis "käsi" tähendab [- - -] käsi on üks osa kehast" ([1933] 1993: 52). Masing tuletab meile meelde hulga igapäevaseid väljendeid, nagu külma käes, tuule käes, päeva kätte, koerte kätte, käest kaduma, mitmekesi (< mitme + käsi). Ta kirjutab, et ega keegi ju ei usu, nagu oleks vanasti arvatud ka koertel olevat käed. Ta väidab, et käsi oli algselt sõna võimu, väe tähistuseks, selle kehaosa tähistamiseks, kus valitseb kellegi meelevald (võrdle käskima). Kui keegi oli külma käes, siis tähendas see seda, et oldi külma meelevallas. Kui keegi sai koerte käest pureda, siis oldi koerte meelevallas. Võim teiste üle oli aga ainult neil, kes liikusid. Selles maailmapildis, kust need näited pärinevad, olid külm, päike, nälg, vihm, tuul, koerad, teised inimesed hingega ja seega liikuvad. Liikumatuil asjul polnud väge. Me ei saa jääda näiteks kivi kätte, kuigi kivil võib olla mõni muu kehaosa: kivile kasvab sammal selga (võrdle ka mäeselg, seljandik). 
Sarnastest näidetest nagu kindad käes, sukad jalas, mis tänapäeva loogika järgi võivad olla üsna vildakad, alustab oma analüüsi Paul Alvre ([1962] 1989). Kuna meil on kaks kätt ja kaks jalga, siis oleks ju palju loomulikum arvata, et kindad on kätes ja sukad-sokid jalgades. Aga ka siin mäletab keel meie muistset maailmapilti. Kõik paariskehaosad, aga ka muud esemed või nähtused, mis moodustasid loomuliku terviku, olidki üks. Neid nimetusi kasutatigi ainsuses. Inimesel oli üks käsi, üks jalg, üks rind, üks põsk jne. Kui taheti osutada osale tervikust, s.t ühele käele, jalale, silmale tänapäeva mõistes, siis tuligi kasutada sõna pool, seega pool kätt või pool jalga. Alvre osutab, et Soomes kutsutakse veel praegugi ühe käega inimest käepooleks (soome käsipuoli) ja ühe jalaga inimest jalapooleks (soome jalkapuoli). See, kes kuuleb ühe kõrvaga, on kõrvapool (soome korvapuoli) ja ühe silmaga, on silmapool (soome silmäpuoli). Ka ungarlastel tähistab szem (silm) kahte silma ning fél-szem (pool silma) tähistab ühte silma. Sellist nähtust - loomulikku kaksust, mis erineb grammatilisest kaksusest ehk duaalist, on laiemalt uurali keeltes käsitlenud Lázló Honti oma artiklis "Mitu silma oli uurallastel?" (1995).

Meie keel mäletab veel seda, et maailm oli üks tervik, kui me ütleme parem või vasak pool. Ka abikaasad moodustavad terviku, kui me räägime teisest poolest kui tugevamast või nõrgemast poolest. Keel mäletab maailmast, ruumist meie ümber palju muudki. Rahvatarkus orienteerus selles ruumis veidi teisiti kui tänapäeval. Kui keegi ütleb, et Jüri seisab tema kõrval, siis ta ometi ei mõtle ju, et Jüri on roninud tema kõrva peale. Juba on meil tegu järgmise näitega - peal. Pane õunad laua peale, õunad on laua peal, võta õunad laua pealt. Kas laual on siis pea otsas, kus miski on, kuhu miskit saab panna või kust miskit saab võtta? Ka see on näide meie esivanemate maailmapildi ruumi koordinaatidest. Inimese pea on üleval, seetõttu on see, mis millelgi, seega üleval, samas ka millegi peal. Kõrv asub inimese küljel, seepärast kõik, mis külje suunal, asub ka kõrval. Kõik, mis lähedal, asub juures. Juur läheb muidugi maasse ja algab sealt, kus kellegi või millegi toetuspunkt. Seesütlev kääne tähendas varem mitte ainult sees olemist, vaid ka lähedal olemist nagu ka väljendites kindad käes ja sukad jalas.

Ruumiga on seotud ka väljend külla minema. Kui me end kenasti riidesse paneme, koogid ja veinipudeli kaasa võtame, kas me hakkame siis põldude või metsade vahelt küla poole vantsima? Kui aga sakslane külla läheb (besuchen), siis peab ta külastatavat enne otsima (suchen). See on pärit nende varasemast maailmapildist, ajast, kui inimasustus oli hõre.

\section{Eestlaste mentaalsest maailmapildist}

Haldur Õim on püüdnud lahata eesti keele mentaalset maailmapilti (1997). Ta toob välja, et meie mentaalne maailmapilt seisab kolmel vaalal - hing, vaim ja meel. Hing ja vaim moodustavad Õimu järgi uuema kihistuse, meel aga kuulub mentaalse maailmapildi vanemasse kihti. Õim tuleb keelematerjali analüüsi puhul järeldusele, et eestlase hing pesitseb südame piirkonnas, sest väljend kogu hingest on sama, mis kogu südamest; hing on raske on sama, mis süda on raske ning hingevalu on samane südamevaluga. Sellega tuleb nõustuda, sest hing oli nn hingushing, oli muiste hingamine. Hingame aga rinnaga ja ütleme vahel praegugi, et hing jäi rinnus kinni. Süües-juues võtame vahel midagi hinge alla, vaesel mehel pole midagi hinge taga. Hing oli igatahes midagi asist.

Kus vaim pesitseb, sellele polegi nii lihtne vastata. Masing on osutanud, et sõna vaim algselt tähendas tuksumisi, mis elustavad keha (1995: 92). Sellest tähendusest on muutunud konkreetseks ka saami vaibmo, vaimo, mis nüüd tähendab südant (süda aga 
tuksub). Masing oletab ka, et vaim on mingis ühenduses seksuaalse sfääriga. Tüdruk võib kinnitada vanematele, kes teda noomivad poisiga magamise pärast: "Ta ep ole ühtegi oma vaimu mu peale puhunud" (Masing 1995: 81). Masing arvab ka, et muiste, umbes aastani 800 oletati mehe ühte hinge asuvat naises. Kas ka vastupidi, pole Masingu järgi kindel. Kui me tuletame meelde, et mees ja naine moodustasid terviku, siis vaimu asumine mehe teises pooles oleks päris usutav. Muistne hinge paralleelnimetus vaim on Soomes hakanudki tähistama (abielu)naist (vaimo).

Meel asub peas, kus asub isegi meelekoht. Õim on märkinud, et meelekoht on sama koht, kuhu näitame sõrmega, kui tahame osutada, et kellegi mõtlemises midagi logiseb (1997: 267). Meel kajastab õieti juba vanemat ununema kippuvat maailmapilti. Õim osutab, et tänapäeva eesti keeles puudub mõiste, mis vastaks inglise sõnale mind. Muistne meel oma hajunud tähenduste ja ajaloolise taustaga vastaks sellele aga väga hästi. Kas meele kadumine näitab tervikmaailmapildi lagunemist, ähmastumist, seda ei julge ma siin väita.

Samas ei ole hinge, vaimu ja meele vahekord üldsegi veel selge. Saksa keele mõjul on nende tähendused ja nendega seotud keelendid oluliselt muutunud. Masingu järgi kuulutati ärkamisajal hing naiselikuks ja vaim mehelikuks. Vaim võrrutati täies ulatuses saksa sõnaga Geist (Masing 1995: 80). Hing seetõttu on enamasti saksa Seele, vahel harva ka Geist. Masingu järgi saksa sõna Sinn vasteks tehti meel, mis paljudel juhtudel sobiski. Edasi meie meele mahtu avardati saksa eeskujul, kujundati viis meeltki, huumor-ilumeel, lisaks veel meeleinstinktid, meeleorganid jt (1998: 360). Meie muistne nägemisvõimus või -võime sai saksa sunnil nägemismeeleks (Masing 1998: 358).

Kui me tuleme meelemärkusele, siis oleme teadvuslikus seisundis. Tänapäeval tähendab see lihtsalt seda, et meie meeled hakkavad jälle toimima. Ei saa kuidagi nõus olla Õimu väitega, et juba algselt tähendas meelemärkus seisundit, kus meeled toimivad (Õim 1997: 266). Nagu juba osutasin, on viis meelt hilised saksa keele eeskujul loodud mõisted.

Vanimasse mentaalse maailmapildi kihistusse, mida keel mäletab, kuulub sõna ise. Ise oli hing, mis arenes välja kahest komponendist: inimest pidevalt saatnud varjust ja unenägudest. Selline ise saatis inimest pidevalt. Alles hilisemal abstraktsiooni astmel oli võimalik nn hingushinge - hinge - kujunemine. Siin on põhjus väga lihtne. Hing lahkub kehast kahel viisil. See, kes läks meie juurest ära, s.t surnu, ei hinga enam. Lovesse langenud šamaan aga hingab, kuigi ka tema hing usutakse olevat kehast lahkunud.

Peale ise ning sõnade hing, vaim ja meel tulevad veel arvesse jumi, vari, leil jt. Edasisel analüüsil tuleb rohkem arvestada, et meel, hing ja vaim on saastatud saksa mõjudega. Et neist muistset rahvatarkust üles leida ja vastavat maailmapilti rekonstrueerida, peame kõigepealt need sõnad saksa mõjudest puhastama. Loomulikult moodustab ka hiline saksastatud rahvatarkus osa meie hilisest maailmapildist. Keel mäletab ka seda.

Mentaalse maailmapildi juurde kuulub ka mentaalsete protsesside kestus ja kiirus. Meie esivanemad mõtlesid ja kõnelesid pikalt ja aeglaselt. Nii mõtlema kui kõnelema, aga ka ütlema, mõnulema, sülelema, väitlema jt on moodustatud frekventatiivse, kordumist, kestust näitava liite -le- abil tüvedest mõte, kõne, üte, mõnu, süle, väide. Nagu kestab mõnulemine, nii ka mõtlemine ja ütlemine. 


\section{Kokkuvõtteks}

Vaadeldud kildude abil nägime, et keel mäletab paljutki meie muistsest rahvatarkusest ja maailmapildist. Nõustun Õimu järeldusega, et kui me tahame rekonstrueerida mentaalset maailmapilti, siis tähendab see väga mahukat tööd, vastava keelematerjali detailset ja mitmetahulist analüüsi. Masingu, Alvre ja Õimu töödega on algus tehtud. Kui meie keelt ja keele mälu hoolega uurida, siis eristades keele kihid ja puhastades need võõrmõjudest, saame elavast keelest rekonstrueerida meie esivanemate muistset maailmapilti ning selle erinevaid kihte.

\section{Kirjandus}

Alvre, Paul 1989. Kehaosi märkivate nimetuste nuumerusest. Kukk, Tiit (toim). Eesti kirja- ja murdekeele morfoloogiat. Tallinn, lk 148-174. (Varem ilmunud ajakirjas Keel ja Kirjandus, 1962: 2, lk 97-104; 3, lk 160-168.)

Honti, Lázló 1995. Wieviel Augen haben die Uralier? Zu Funktionen der Numeri im Uralischen. Künnap, Ago (ed). Minor Uralic Languages: Grammar and Lexis. Tartu \& Groningen, lk 73-87.

Masing, Uku 1993. Hüpoteetilist eesti keele psühholoogiast. Krikmann, Luule (toim). Vaatlusi maailmale teoloogi seisukohalt. Tartu, lk 51-55. (Varem ilmunud ajakirjas Olion 1933: 3).

Masing, Uku 1995. Lääts, Anti (toim). Eesti usund. Tartu.

Masing, Uku 1998. Mõtteteaduse sõnavara olukorrast. Tõnisson, Urmas (toim). Meil on lootust. Runnel, Hando \& Tõnisson, Urmas (koost). (Eesti mõttelugu, 19.) Tartu, lk 355361.

Sutrop, Urmas 1999. Evolutsiooniline psühholoogia: kas meie teadvus on pärit kiviajast? Vikerkaar, nr 2-3.

Tulviste, Peeter 1998. Etnopsühholoogiast ja meist. Rektoriraamat: artikleid, sõnavõtte, intervjuusid. Orav, Mart (koost \& toim). Tartu, lk 53-57. (Esmalt ilmunud ajalehes Edasi 5. VIII 1988, nr 179: 3).

Õim, Haldur 1997. Eesti keele mentaalse maailmapildi allikaid ja piirjooni.

Pühendusteos Huno Rätsepale: 28. 12. 1997. Erelt, Mati \& Sedrik, Meeli \& Uuspõld, Ellen (toim). (Tartu Ülikooli eesti keele õppetooli toimetised, 7.) Tartu, lk 255-268. 